\title{
Article \\ The influence of height of the weld reinforcement on the cost of additional materials in MAG welding process (135)
}

\author{
Katarzyna Kochanowska ${ }^{1,}{ }^{*}$, Ryszard Pakos ${ }^{2}$ \\ ${ }^{1}$ JW Steel Construction; \\ 2 West Pomeranian University of Technology, Szczecin; \\ Ryszard Pakos, Ph. D.; r.pakos@vp.pl; \\ * Correspondence: Katarzyna Kochanowska, M. Sc.; katarzynakasiak94@gmail.com
}

Received: 02.06.2019; Accepted: 10.11.2019

\begin{abstract}
This article analyzes influence of the height of the weld reinforcement on the cost of additional materials in the MAG welding process. For this purpose, a simple calculator was created based on which the welds were calculated in the quality levels B, C and D and the costs of additional materials for butt joints made of low-alloy and high-alloy steel and T-joints made of low-alloy steel. Considerations on this subject were carried out based on the PN-EN ISO 5817 standard defining quality levels according to welding nonconformities. The losses resulting from exceeding a given quality level are presented.
\end{abstract}

Keywords: height of the reinforcement, quality level, direct costs

\section{Introduction}

Appropriate management of expenses in the company is the basis that determines its development and competitiveness on the market [1]. Expenses monitoring and their proper planning allows to reduce the costs of the enterprise's operation. Optimization of costs is primarily an analysis of expenses, even small ones, which in mass production can bring significant savings [2]. The reduction of burdens allows investment of saved funds in enterprise development [3]. Independent analysis of expenses is not a bargain thing, because very often some of them are omitted and considered insignificant, thus the picture of costs incurred is not full [4]. In the case of analyzes, it is worth using software that will minimize the possibility of making a mistake during the calculation [5].

\section{Losses of additional material resulting from failure to meet the assumed quality level}

The economics of producing steel structures are influenced by many factors, including manufacturing cost, sale price and profit [6]. To start cost-related analyzes and take remedial actions to optimize costs, you must skillfully separate the components [7]. B determining the percentage share of costs, we receive information on which of them can be reduced. For the purposes of welding cost analysis, two types are distinguished [8]:

- direct costs that can be related to a given product, e.g. consumption of additional materials, direct labor costs, electricity consumption;

- indirect costs, they cannot be directly related to the product, e.g. management costs, administration, maintenance, taxes [9].

In order to analyze direct costs, including the costs of additional material (shielding gas and welding wire adopted at: http://www.lincolnelectric.com/ in force on the date of 03.02.2019) using the MAG method for the joints in three quality levels, a calculator was created in the program Excel of the Microsoft Office suite (Fig. 1) [10].

Based on the literature [11] and the requirements of PN-EN ISO 5817, the parameters of the joints were calculated in given quality levels, i.e.: the width of the face and the height of the reinforcement [11]. It was assumed that the groove welds were bevelled at $\mathrm{V}$ with a groove angle of $60^{\circ}$ and a distance of $3 \mathrm{~mm}$. Direct costs were calculated for butt joints in thickness ranges from 10 to $60 \mathrm{~mm}$ made of low-alloy and highalloy steel to illustrate the difference resulting from the price of the additional material used for the welding 
process. In addition, costs were calculated for T-joints with fillet welds for joint thicknesses from 5 to $10 \mathrm{~mm}$ made of low-alloy steel. In the calculation of weld masses for the MAG method, a weld metal index of 0.97 was taken into account [2].

\begin{tabular}{|c|c|c|}
\hline \multicolumn{3}{|c|}{ POZıOM JAKOŚCI } \\
\hline \multirow[t]{2}{*}{ B } & \multicolumn{2}{|c|}{ Proces Spawania -dane wejściowe } \\
\hline & RODZIAJ UKOSOWANIA & $\mathrm{v}$ \\
\hline & GRUBOSC BLACHY [mm] & 30 \\
\hline & KATT ROWKA [ ${ }^{\circ}$ ] & 60 \\
\hline & DtUGOŚć SPOINY [mm] & 1000,00 \\
\hline & KOSZT gazu [zt/kg] & $6,60 \mathrm{zt}$ \\
\hline & KOSZT drutu [zt/kg] & $11,00 \mathrm{zt}$ \\
\hline & ODSTĘP [mm] & 5 \\
\hline & promień - r (dla ukosoania na "U") & 8 \\
\hline & WSPÓtCZYNNIK JARZENIA SIĘ tUKU & $20,00 \%$ \\
\hline & WYDAJNOŚĆ STAPIANIA $\mathrm{kg} / \mathrm{h}$ & 3 \\
\hline & STAWKA GODZINOWA SPAWACZA [zt/h] & 20 \\
\hline & NATĘŻENIE PRĄDU SPAWANIA [A] & 110 \\
\hline & NAPIĘCIE tUKU [V] & 16,3 \\
\hline & CENA ENERGI ELEKTRYCZNE] [zt/kWh] & 0,55 \\
\hline
\end{tabular}

\begin{tabular}{|c|c|}
\hline \multicolumn{2}{|l|}{ Dane wyjściowe } \\
\hline POLE POWIERZCHNI WEWNACTRZ ROWKA SPAW. $[\mathrm{mm}]^{\wedge} 2$ & 669,62 \\
\hline POLE POWIERZCHNI SPOINY W NADLEWIE [mm]^ 2 & 135,47 \\
\hline OBJĘTOŚĆ SPOINY [mm^3] & 805085,30 \\
\hline ROZWARCIE ROWKA [mm] & 37,64 \\
\hline WYSOKOSC NADLEWU "h" [mm] & 5,00 \\
\hline SZEROKOŚĆ LICA SPOINY [mm] & 40,64 \\
\hline MASA SPOINY [kg/m] & 6,51 \\
\hline MASA SPOINY [kE] & 6,51 \\
\hline Koszt drutu [zl/m] & 73,82 zt \\
\hline Koszt gazu [z1/m] & $31,00 \mathrm{zt}$ \\
\hline Koszt materiału dodatkowego $[z 1 / \mathrm{m}]$ & 104,82 zf \\
\hline CZAS SPAWANIA [h] & 10,85 \\
\hline KOSZT ROBOCIZNY BEZPOŚREDNIEJ & $260,38 \mathrm{zt}$ \\
\hline KOSZT ENERGII ELEKTRYCZNE J & 4,28 zt \\
\hline LA CZNE KOSZTY BEZPOŚREDNIE & $369,48 \mathrm{zt}$ \\
\hline
\end{tabular}

Fig. 1. Calculator for calculating the direct costs of welding with the height of the reinforcement in the quality level B [3]

Table I assumes the maximum height of the reinforcement at given quality levels resulting from the width of the face. In the event that the calculated reinforcement in given quality levels exceeded the maximum value, constant values corresponding to the given levels, i.e. the order of 5, 7 and $10 \mathrm{~mm}$, were assumed. In order to illustrate the losses resulting from the transition from level B to level C or even D, the graph (Fig. 2) shows the mass differences at the thickness of the butt joint made of low-alloy steel.

Table I. List of costs of additional material for low alloy steel [4]

\begin{tabular}{|c|c|c|c|c|}
\hline \multicolumn{5}{|c|}{ Groove weld - butt jont - LOW-ALLOY STEEL } \\
\hline \multirow{2}{*}{$\begin{array}{c}\text { Thickness } \\
\text { [mm] }\end{array}$} & \multirow{2}{*}{ Measured quantity } & \multicolumn{3}{|c|}{ Level of quality } \\
\hline & & B & C & D \\
\hline \multirow{4}{*}{10} & face width [mm] & 17.55 & 17.55 & 17.55 \\
\hline & height of the reinforcement $[\mathrm{mm}]$ & 2.75 & 3.63 & 5.99 \\
\hline & weld mass $[\mathrm{kg} / \mathrm{m}]$ & 0.97 & 1.05 & 1.22 \\
\hline & cost of additional material [PLN/m] & 11.42 & 12.4 & 14.55 \\
\hline \multirow{3}{*}{20} & face width [mm] & 29.09 & 29.09 & 29.09 \\
\hline & weld mass $[\mathrm{kg} / \mathrm{m}]$ & 2.97 & 3.19 & 3.65 \\
\hline & cost of additional material [PLN/m] & 34.91 & 37.60 & 42.97 \\
\hline \multirow{4}{*}{30} & face width [mm] & 40.64 & 40.64 & 40.64 \\
\hline & height of the reinforcement [mm] & 5 & 7 & 10 \\
\hline & weld mass $[\mathrm{kg} / \mathrm{m}]$ & 6.02 & 6.46 & 7.12 \\
\hline & cost of additional material [PLN/m] & 70.93 & 76.08 & 83.82 \\
\hline \multirow{4}{*}{40} & face width $[\mathrm{mm}]$ & 52.19 & 52.19 & 52.19 \\
\hline & height of the reinforcement [mm] & 5 & 7 & 10 \\
\hline & weld mass $[\mathrm{kg} / \mathrm{m}]$ & 9.85 & 10.41 & 11.25 \\
\hline & cost of additional material [PLN/m] & 115.92 & 122.54 & 132.48 \\
\hline \multirow{4}{*}{50} & face width [mm] & 63.74 & 63.74 & 63.74 \\
\hline & height of the reinforcement [mm] & 5 & 7 & 10 \\
\hline & weld mass $[\mathrm{kg} / \mathrm{m}]$ & 14.6 & 15.29 & 16.32 \\
\hline & cost of additional material [PLN/m] & 171.90 & 179.99 & 192.12 \\
\hline \multirow{4}{*}{60} & face width [mm] & 75.28 & 75.28 & 75.28 \\
\hline & height of the reinforcement [mm] & 5 & 7 & 10 \\
\hline & weld mass $[\mathrm{kg} / \mathrm{m}]$ & 20.29 & 21.1 & 22.32 \\
\hline & cost of additional material [PLN/m] & 238.88 PLN & 248.42 PLN & 262.76 PLN \\
\hline
\end{tabular}

The chart (Fig. 2) shows the relationship between the thickness of the joint and the difference in mass of welds for individual quality levels. These differences can be up to $2 \mathrm{~kg}$ per 1 running meter of weld. Considering the price of additional materials presented in table I, the loss may be approx. PLN 24 gross per 
meter of weld. This value applies to losses while welding low-alloy steel. When welding high alloy steel, these values are much higher due to the higher costs of welding consumables. The price of high-alloy steel welding wire is approx. PLN 40 per $\mathrm{kg}$ [15].

In order to compare the costs of additional materials for low-alloy and high-alloy steel, calculations were made with the same welding parameters, bevelling method, welded joint dimensions - height of the reinforcement and face width (Table II).

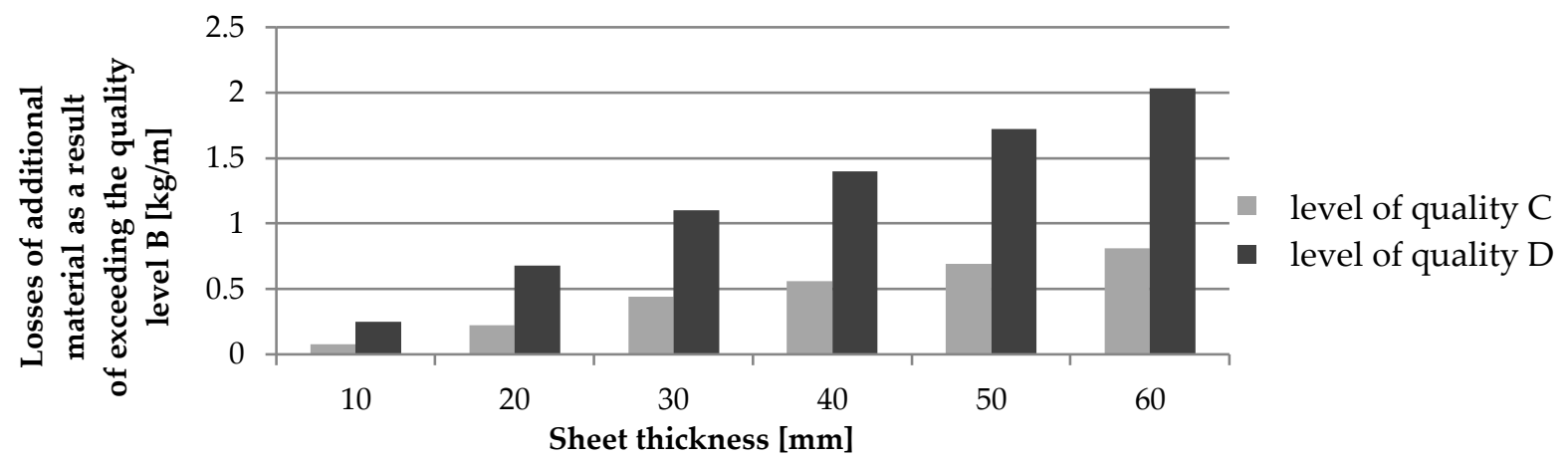

Fig. 2. Graph of the dependence of losses of additional materials as a result of exceeding the quality level B from the thickness of the joint
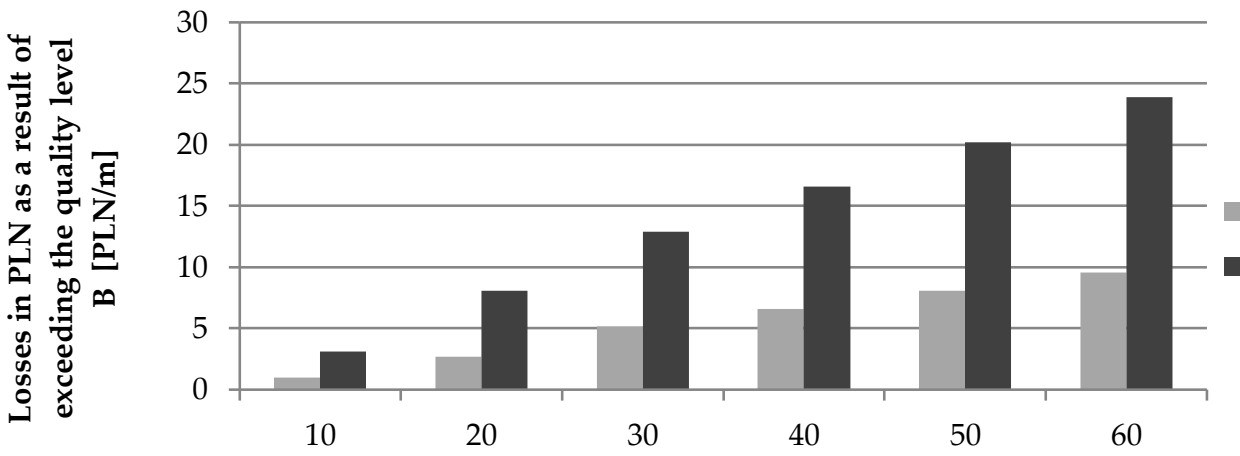

level of quality C

level of quality D

Sheet thickness [mm]

Fig. 3. Graph of the dependence of losses in PLN as a result of exceeding the quality level B from the thickness of the low-alloy joint

Material losses also increase linearly and depend on the thickness of the joint. In the case of the $60 \mathrm{~mm}$ thick joint variant by making the joint in the quality level D instead of B, the losses are almost PLN 95 for each meter of weld, which corresponds to an increase in the use of material by over $9 \%$.

Exceeding the quality level B generates additional material losses from $21.51 \%$ for joints with a thickness of $10 \mathrm{~mm}$ to $9.09 \%$ for joints with a larger thickness.

Based on the graph (Fig. 2), it can be seen that the cost of additional material for low-alloy steel joints is almost four times higher.
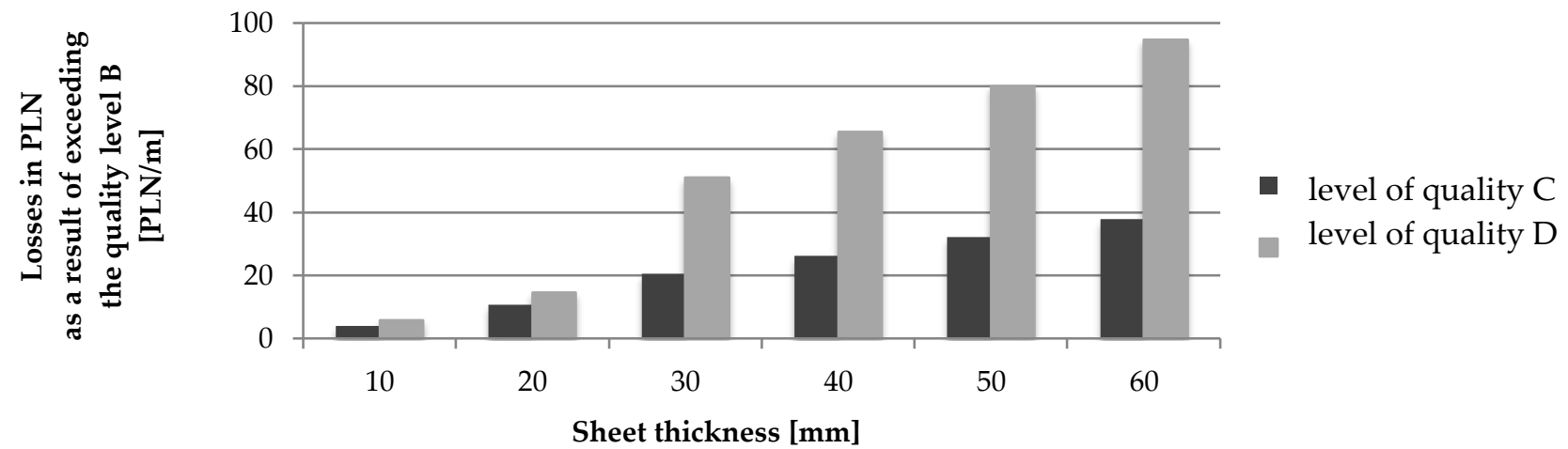

Fig. 4. Graph of the dependence of losses in PLN as a result of exceeding the quality level B from the thickness of the high-alloy joint 
Table II. List of costs of additional material for high-alloy steel

\begin{tabular}{|c|c|c|c|c|}
\hline \multicolumn{5}{|c|}{ Groove weld - butt jont - HIGH-ALLOY STEEL } \\
\hline \multirow{2}{*}{ Thickness [mm] } & \multirow{2}{*}{ Measured quantity } & \multicolumn{3}{|c|}{ Level of quality } \\
\hline & & B & $\mathrm{C}$ & D \\
\hline \multirow{4}{*}{10} & face width [mm] & 17.55 & 17.55 & 17.55 \\
\hline & height of the reinforcement $[\mathrm{mm}]$ & 2.75 & 3.63 & 5.99 \\
\hline & weld mass $[\mathrm{kg} / \mathrm{m}]$ & 0.97 & 1.05 & 1.22 \\
\hline & cost of additional material [PLN/m] & 45.22 & 49.09 & 51.02 \\
\hline \multirow{4}{*}{20} & face width [mm] & 29.09 & 29.09 & 29.09 \\
\hline & height of the reinforcement [mm] & 3.91 & 5.36 & 8.27 \\
\hline & weld mass $[\mathrm{kg} / \mathrm{m}]$ & 2.97 & 3.19 & 3.65 \\
\hline & cost of additional material [PLN/m] & 138.25 & 148.88 & 152.77 \\
\hline \multirow{4}{*}{30} & face width [mm] & 40.64 & 40.64 & 40.64 \\
\hline & height of the reinforcement [mm] & 5 & 7 & 10 \\
\hline & weld mass $[\mathrm{kg} / \mathrm{m}]$ & 6.02 & 6.46 & 7.12 \\
\hline & cost of additional material [PLN/m] & 280.85 & 301.27 & 331.91 \\
\hline \multirow{4}{*}{40} & face width [mm] & 52.19 & 52.19 & 52.19 \\
\hline & height of the reinforcement [mm] & 5 & 7 & 10 \\
\hline & weld mass $[\mathrm{kg} / \mathrm{m}]$ & 9.85 & 10.41 & 11.25 \\
\hline & cost of additional material [PLN/m] & 459.00 & 485.23 & 524.57 \\
\hline \multirow{4}{*}{50} & face width [mm] & 63.74 & 63.74 & 63.74 \\
\hline & height of the reinforcement [mm] & 5 & 7 & 10 \\
\hline & weld mass $[\mathrm{kg} / \mathrm{m}]$ & 14.6 & 15.29 & 16.32 \\
\hline & cost of additional material [PLN/m] & 680.68 & 712.71 & 760.76 \\
\hline \multirow{4}{*}{60} & face width [mm] & 75.28 & 75.28 & 75.28 \\
\hline & height of the reinforcement [mm] & 5 & 7 & 10 \\
\hline & weld mass $[\mathrm{kg} / \mathrm{m}]$ & 20.29 & 21.1 & 22.32 \\
\hline & cost of additional material [PLN/m] & 945.88 & 983.71 & 1040.47 \\
\hline
\end{tabular}

Table III. List of material losses expressed as a percentage resulting from exceeding the quality level

\begin{tabular}{ccc}
$\begin{array}{c}\text { Joint } \\
\text { thickness } \\
\text { [mm] }\end{array}$ & $\begin{array}{c}\text { The increasing amount of additional } \\
\text { material after changing the level from B to }\end{array}$ & $\begin{array}{c}\text { The increasing amount of additional } \\
\text { material after changing the level from B to } \\
\text { D }\end{array}$ \\
\hline 10 & $7.90 \%$ & $21.51 \%$ \\
20 & $7.15 \%$ & $12.50 \%$ \\
30 & $6.77 \%$ & $15.38 \%$ \\
40 & $5.40 \%$ & $12.50 \%$ \\
50 & $4.49 \%$ & $10.52 \%$ \\
60 & $3.84 \%$ & $9.09 \%$ \\
\hline
\end{tabular}

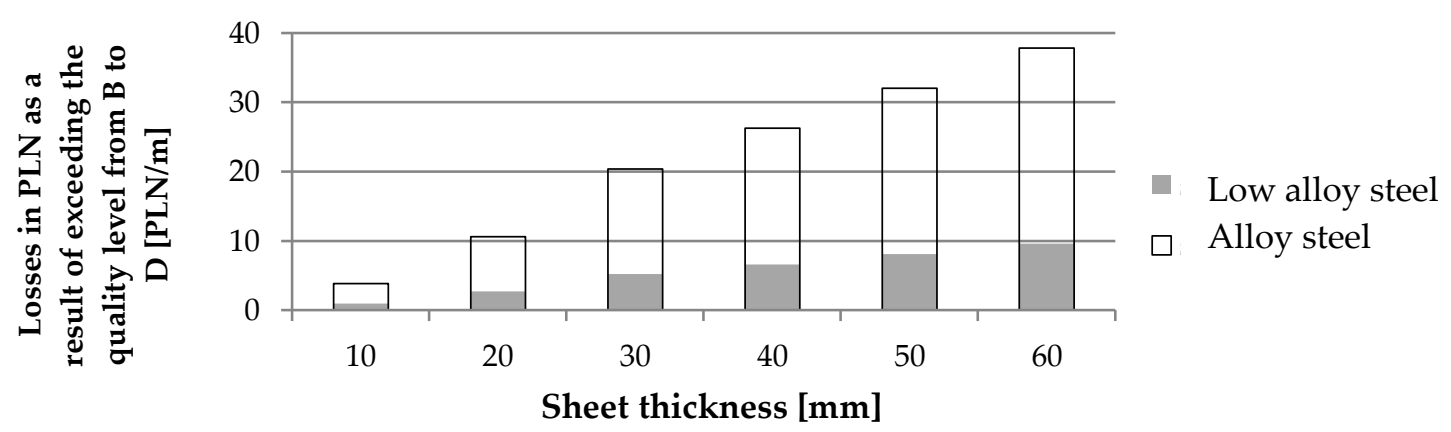

Fig. 5. Comparison of losses in PLN incurred as a result of exceeding the quality level B for C for low-alloy and highalloy steel 


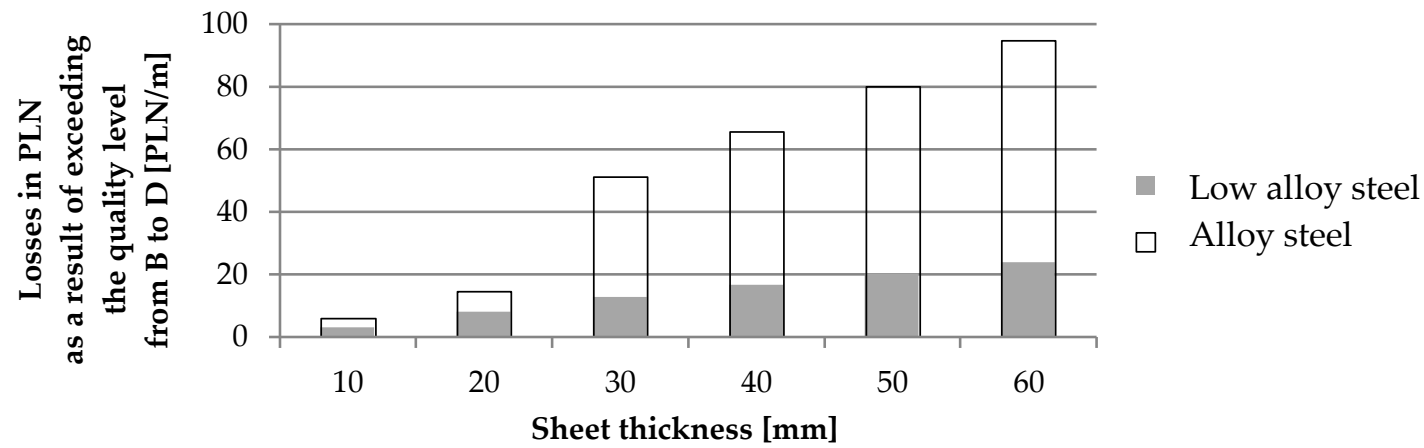

Fig. 6. Comparison of losses in PLN incurred as a result of exceeding the quality level B for D for low-alloy and highalloy steel

Even higher costs are generated in the case of a joint made in the quality level D instead of B. In the case of joints with a thickness of $10 \mathrm{~mm}$, these costs are relatively small (within 4 PLN on a section of $1 \mathrm{~m}$ ) compared to a joint with a thickness of $60 \mathrm{~mm}$.

A comparison of the percentage share of the cost of additional material in the amount of direct costs is presented in pie charts for butt joints of low-alloy and high-alloy steel (Fig. 7).

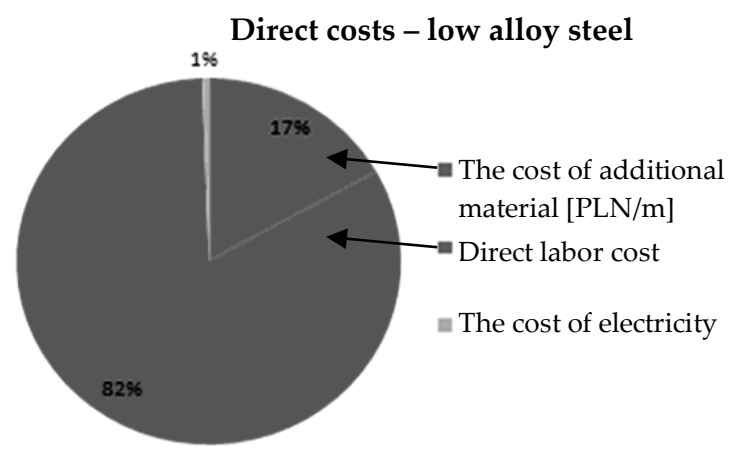

(a)

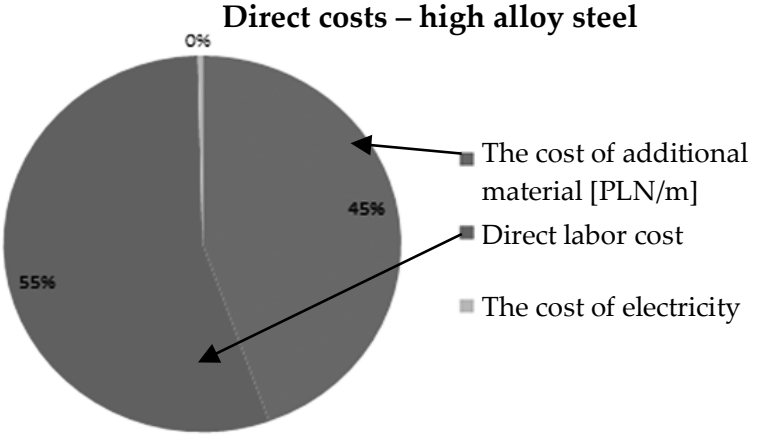

(b)

Fig. 7. Division of direct welding costs for a) low-alloy steel, b) high-alloy steel

In the case of low-alloy steel, the cost of additional material accounts for $17 \%$ of direct costs, regardless of the quality level of the joint, because the higher the reinforcement, the greater the share of labor costs. The cost of electricity accounts for around 1\% of direct costs. Analyzing the structure of direct costs of welded joints of high-alloy steel it can be seen that almost half are additional materials. Labor costs are $55 \%$ of the costs, while electricity costs are a fraction of a percent.

The next part presents the costs of welding $\mathrm{T}$-joints in the $5 \div 10 \mathrm{~mm}$ thickness range. Calculations were made for fillet welds made of steel grade S355. The results are shown in table IV and figure 8.

After analyzing the data contained in table IV, it can be seen that the costs of additional materials are relatively low (from PLN 2.44 to 10.06 per running meter of weld) and the differences in the case of exceeding the quality levels are small (from PLN 0.95 to 2.48 per running meter of weld), however, in the case of mass production, they can significantly reduce profit. To illustrate the data, these relationships are presented as a percentage in table $\mathrm{V}$.
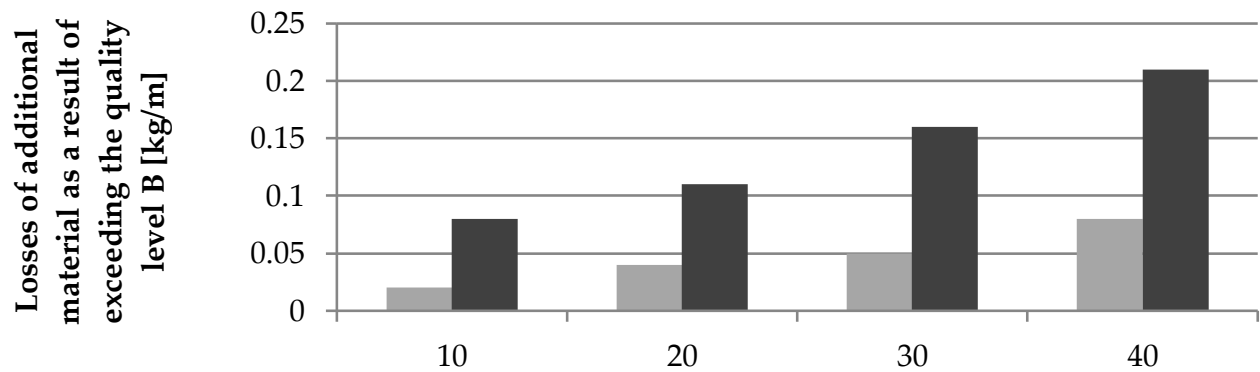

- level of quality C

- level of quality D

Sheet thickness [mm]

Fig. 8. Graph of the dependence of losses of additional materials as a result of exceeding the quality level B from the thickness of the joint 
Table IV. List of costs of additional material for fillet joints

Fillet weld - T-joint

\begin{tabular}{|c|c|c|c|c|}
\hline \multirow{2}{*}{ Thickness [mm] } & \multirow{2}{*}{ Measured quantity } & \multicolumn{3}{|c|}{ Level of quality } \\
\hline & & B & $\mathrm{C}$ & D \\
\hline \multirow{4}{*}{5} & face width [mm] & 10 & 10 & 10 \\
\hline & height of the reinforcement [mm] & 2 & 2.5 & 3.5 \\
\hline & weld mass $[\mathrm{kg} / \mathrm{m}]$ & 0.21 & 0.23 & 0.29 \\
\hline & cost of additional material [PLN/m] & 2.44 & 2.75 & 3.39 \\
\hline \multirow{4}{*}{6} & face width [mm] & 11.40 & 11.40 & 11.40 \\
\hline & height of the reinforcement [mm] & 2.14 & 2.71 & 3.85 \\
\hline & weld mass $[\mathrm{kg} / \mathrm{m}]$ & 0.27 & 0.31 & 0.38 \\
\hline & cost of additional material [PLN/m] & 3.23 & 3.64 & 4.46 \\
\hline \multirow{4}{*}{8} & face width [mm] & 14.20 & 14.20 & 14.20 \\
\hline & height of the reinforcement [mm] & 2.42 & 3.13 & 4.55 \\
\hline & weld mass $[\mathrm{kg} / \mathrm{m}]$ & 0.44 & 0.49 & 0.60 \\
\hline & cost of additional material [PLN/m] & 5.17 & 5.81 & 7.09 \\
\hline \multirow{4}{*}{10} & face width [mm] & 17.00 & 17.00 & 17.00 \\
\hline & height of the reinforcement [mm] & 2.7 & 3.55 & 5 \\
\hline & weld mass $[\mathrm{kg} / \mathrm{m}]$ & 0.64 & 0.72 & 0.85 \\
\hline & cost of additional material [PLN/m] & 7.58 & 8.49 & 10.06 \\
\hline
\end{tabular}

Table V. List of material losses expressed as a percentage resulting from exceeding the quality level

\begin{tabular}{ccc}
$\begin{array}{c}\text { Joint } \\
\text { thickness } \\
{[\mathrm{mm}]}\end{array}$ & $\begin{array}{c}\text { Losses of additional material as a result of } \\
\text { making the joint in the quality level C instead } \\
\text { of B }\end{array}$ & $\begin{array}{c}\text { Losses of additional material as a result of } \\
\text { making the joint in the quality level D instead } \\
\text { of B }\end{array}$ \\
\hline 5 & $8.70 \%$ & $27.59 \%$ \\
6 & $12.90 \%$ & $18.42 \%$ \\
8 & $10.20 \%$ & $26.67 \%$ \\
10 & $11.11 \%$ & $24.71 \%$ \\
\hline
\end{tabular}

Material losses in case of exceeding the B quality level for T-joints are from $8.70 \%$ to $27.59 \%$ for the considered cases. The cost structure of direct T-joints is the same as for butt joints (Fig. 9).

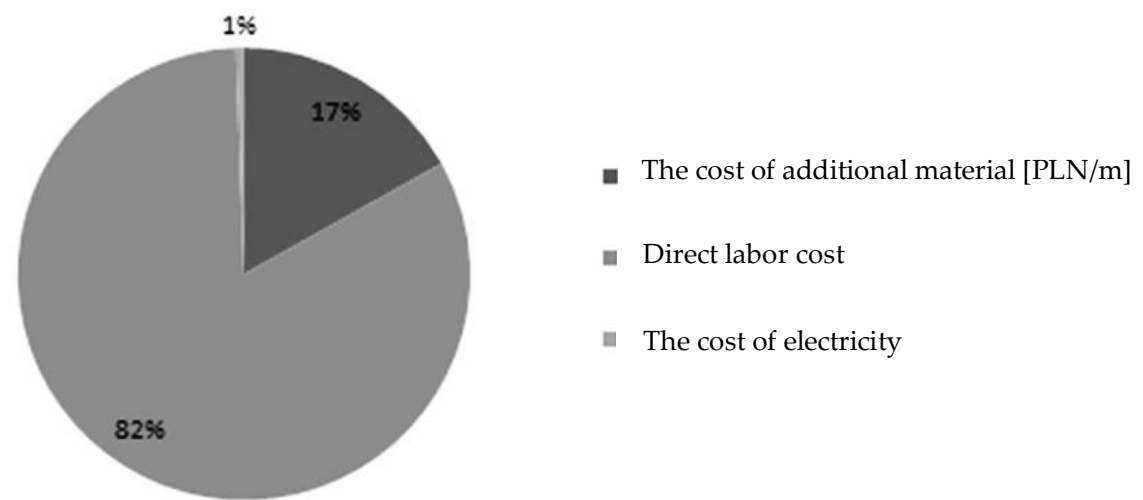

Fig. 9. Structure of direct costs for low alloy steel T-joint

\section{Summary}

Based on the analyzes carried out, the following conclusions were formulated:

- butt joint at the $\mathrm{C}$ quality level (assuming the required level B), generates losses of approx. $4 \%$ for a 60 mm thick joint to approx. $8 \%$ for a $10 \mathrm{~mm}$ thick joint;

- butt joint at the D quality level increases the cost of additional materials from approx. $9 \%$ (joints with a thickness of $60 \mathrm{~mm}$ ), to as much as approx. $22 \%$ for joints with smaller thicknesses - $10 \mathrm{~mm}$;

- for low-alloy steel, losses translate into amounts from 3.13 to 23.88 PLN for each meter of the butt joint;

- with the same mass of welds, losses resulting from butt joints made of high alloy steel (thickness ranges from 10 to $60 \mathrm{~mm}$, quality level D) vary from 5.80 to 94.59 PLN for each meter of the joint; 
- the percentage of additional material costs in the total direct costs in the case of low-alloy steel is $17 \%$ and high-alloy steel $45 \%$;

- direct labor costs have the largest share in the structure of direct costs, with $82 \%$ for low-alloy steel joints and only $45 \%$ for high-alloy steel joints;

- electricity costs in the structure of direct costs are at the level of $1 \%$;

- when considering the thickness range of T-joints, the recommendation was made that the thickness of the weld should be in the range of $2.5 \div 16 \mathrm{~mm}$;

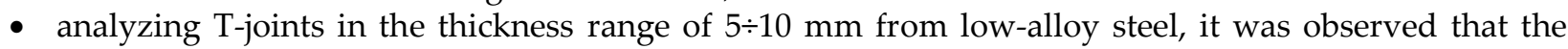
distribution of direct costs is the same as in the case of low-alloy steel butt joints;

- material losses in case of exceeding the quality level B for T-joints are from 8.70 to $27.59 \%$ for the considered cases;

- due to small ranges of fillet weld thickness, losses expressed in PLN/m are lower and range from 0.64 to $2.47 \mathrm{PLN} / \mathrm{m}$, but very often these joints are made with excessive convexity, additionally the thickness of the joint is measured mistakenly.

Author Contributions: conceptualization M.B. and J.S., methodology M.B. and J.S.; investigation M.B.; discussion M.B. and J.S., writing - original draft preparation M.B. and editing J.S.

Conflicts of Interest: The authors declare no conflict of interest.

\section{References}

[1] Keane M.J., Siert A., Chen B.T., Stone S.G., Profiling Mild Steel Welding Processes to Reduce Fume Emissions and Costs in the Workplace, Oxford Journal, December 2013.

[2] Pilarczyk J. (red.), Poradnik Inżyniera, Spawalnictwo, tom 1. WNT, Warszawa 2003.

[3] Pilarczyk J., Zeman W., Economics and quality in welding, VI Krajowa Naukowo-Techniczna Konferencja Spawalnicza - Jakość w spawalnictwie. Międzyzdroje, 8-10.05.2001.

[4] www.is.gliwice.pl (odczyt z dnia 29.09.2019)

[5] Restecka M., Calculation of welding costs using information systems, Welding Technology Review, 2016 , Vol. 88(5), 28-33. [CrossRef]

[6] Wińcza M., Zeman W., Economics of the production of welded steel structures, Welding Technology Review, 2001, Vol. 73(2-3), 1-6.

[7] Drucker P.F., Innovation and Enterpreneuership, Harper Collins Publisher, Washington 2002.

[8] Zeman W., Kurpisz B., Ekonomika wytwarzania konstrukcji spawanych. Poradnik inżyniera, Spawalnictwo, 2003.

[9] Benway E.A., Lowering the cost of orbital welding, Pristine Processing, January 2004.

[10] Nowacki J., Pakos R., Kosek S., Computer aided welding cost calculations, Welding Technology Review, 2007, Vol. 79(4), 4-12.

[11] Silva C., Ferraresi V., Scotti A., A quality and cost approach for welding process selection, Journal of the Brazilian Society of Mechanical Sciences, 2000, Vol. 22(3). [CrossRef]

[12] http://www.lincolnelectric.com (odczyt z dnia 29.09.2019)

[13] Miller K.D., Determining the cost of welding, Welding Design and Fabrication, 2004, 3.

[14] Example of cost calculation in welding, Technical Sheets of EWF, 2007.

[15] Grundman J., Quality, efficiency and the resulting costs of welding carbon steels in an active gas shield, Biuletyn Instytutu Spawalnictwa, 2005, Vol. 49(5), 111-116.

(C) 2019 by the authors. Submitted for possible open access publication under the terms and conditions of the Creative Commons Attribution (CC BY) license (http://creativecommons.org/licenses/by/4.0/). 